\title{
"STAYING AFLOAT VIA GUANXI: STUDENT NETWORKS, SOCIAL CAPITAL AND INEQUALITY IN CHINESE ADULT HIGHER EDUCATION"
}

\author{
First author: Shanshan Guan \\ Institute: Faculty of Education, East China Normal University, Shanghai, China \\ Email: shanshanguan0123@gmail.com
}

Second author (corresponding author): Dr Fiona James

Institute: School of Education, Faculty of Arts, Cultures and Education (FACE), University of Hull, Hull, UK.

Email: F.James@hull.ac.uk 


\begin{abstract}
This study illuminates students' purposive cultivation of guanxi, or social networks based on continuous exchange of resources, in the context of China's Adult Higher Education system. Interviews with 30 students reveal the motivations underpinning their creation of informal ties amongst peers, which they consider to procure beneficial resources for the present and long-term. They deem guanxi with peers to compensate for the isolation they experience. Such experiences, taken in the context of a competitive Higher Education and graduate employment landscape, are then related to social capital. The marriage of the concepts guanxi and social capital is also discussed in light of our analysis.
\end{abstract}

Key words: mature students, China, higher education, guanxi, social capital

\title{
1. INTRODUCTION
}

Social capital, although a difficult concept to pinpoint, has been argued to be intertwined with one's progression in the education system (De Vries and Renfrow, 2016; Field, 2015; Reay, et al. 2002). The enabling qualities of social capital in Higher Education (HE) are becoming more widely recognised and substantiated (Fearon et al., 2018). It is not only academic success but the accrual of skills required for networking with others that is arguably significant in a HE landscape shaped by market forces. The idea that social capital is related to students' connections and ability to follow the unwritten or tacit rules of the system (Bathmaker, et al., 2013; Crozier and Reay, 2011) provides grist for analysis regarding inequality within HE. Structural inequalities within China's system, arising from its somewhat piecemeal developmental trajectory, are 
becoming more widely acknowledged (Chen and Wu, 2011; Qin, 2016; Zhao, 2016). Its transformation and transitioning from 'elite to mass' (Shan and Guo, 2014, p.12), has sparked concerns over inequality amidst rising numbers and uneven resourcing across types of HE provision (Jiang, 2017; Yang, 2005). However, empirical studies are scarce.

Frequently construed as 'non-mainstream', mature students as a group have been the subject of attention in the Anglophone research literature in terms of their marginalisation (Morris, 2009). This arises in connection to what has been argued to be a HE system perpetuating inequality (Bourdieu, 1977; Sissel et al., 2001). Those such as Reay et al. (2002) who have explored the group's characteristics attest to their unique needs, especially their feelings of dislocation from a secure idea of who they are in such contexts. They are therefore more likely to seek community with those with whom they feel affinity. However, comparatively, considerably less is known about mature students as a group in the Chinese context. The Chinese equivalent to mature students are those studying within the Adult Higher Education System (AHE). The interview data in our study pertain to such students.

The few studies focusing on students within AHE have not adopted the concept of social capital explicitly to pursue concerns over inequality. The notion of capital, which refers to resources accrued - whether economic or built up through familiarity with a system - only appears in Wang and Morgan's (2009) research. In an investigation into AHE students' marginalisation, Wang and Morgan deploy the concept of human capital, understood in terms of productivity within the workforce, to illuminate AHE students' positioning in the market. Human capital is arguably a more directly market-based, 
measurable construct compared to social capital, though it does not foster understanding of how capital accrues through students' social connections. This is where the concept of social capital can provide further insight.

In China, guanxi, a form of connectivity deeply entrenched in culture involving the continuous 'exchange of favours' (Liu, 2008, p.64) between people is the closest concept to social capital as conceived in Anglophone literature. Qi (2013) theorises that by virtue of its continuous, directly reciprocal exchanges, guanxi fosters greater explication of connectivity and associated social norms than the westernised concept of social capital. Guanxi has also been noted to have risen to prominence as a social practice in relation to the acquisition of job contacts and inside-information within China's marketised, competitive employment landscape (Bian, 2018). However, while guanxi has been investigated extensively in connection with the field of business, it has not been studied in relation to the HE system in China. The inequality noted in the Anglophone literature regarding HE students' social capital (for example, Bathmaker, et al., 2013) has inspired our qualitative inquiry into Chinese AHE students' social connectivity and subjective experiences in the unequal situation posited by Chen and Wu (2011), Qin (2016), and Zhao (2016).

Social, human, economic, symbolic and cultural forms of capital are regularly paired with HE in the Anglophone literature, though social capital remains the most opaque concept. This, according to Adler and Kwon (2002), is due to the intangibility of its embedded notions such as trust that are not amenable to direct measurement, and the potential quality of social capital in the sense that it is stored in anticipation of reciprocated future exchange of resources. Those deploying social capital in empirical 
studies (for example, Jensen and Jetten, 2015) attest to its mutability, contending it is not the 'static property of the individual' (Field, 2015, p.16). It remains unclear, however, how its processual elements might be captured empirically. Social capital is a purely analytic construct so unlikely to be referred to directly by research participants. Conversely, the social practice of guanxi would be a term adopted since it is firmly embedded in every day parlance.

Our study sheds light upon AHE student interviewees' purposeful cultivation of guanxi in direct relation to the struggles they articulate at university. The article begins by outlining the political and socio-economic context of Chinese $\mathrm{HE}$ and its dual nature. The concepts social capital and guanxi are expounded before research literature connecting them to HE contexts is reviewed. An analysis of interview data follows, elucidating interviewees' deliberate use of guanxi. The marriage of social capital and guanxi to enhance understanding of inequality in $\mathrm{HE}$ is then discussed in light of our qualitative findings.

\section{Chinese Adult Higher Education System (AHE)}

Currently, two parallel HE systems exist in China: 'regular' and 'adult'. 'Regular' HE (RHE) targets students transitioning from high school who take the highly competitive Higher Education Entrance Examination that serves as the gateway to bachelor degree study. The 'adult' AHE, which has a greater vocational orientation than RHE, is associated with the first-degree diploma awarded to working adults. Chinese HE law (Yu, 2010) espouses that adults, regardless of factors like age, marital status 
and occupation have the right to participate in the Higher Education Entrance Examination and access RHE. However, they are stymied by fierce competition over accessing RHE and its full-time study mode. Studying in RHE would mean giving up paid work, rendering the part-time study offered by AHE more appealing. Studying part-time, as 'mature students', as they are known in China, enables adults to obtain a first-degree certificate provided by AHE (Wang and Jiao, 2016).

Since the launch of HE expansion in 1999 by the Chinese government, annual enrolment of undergraduate students has grown considerably (MoE, 2016a). However, the way the AHE system operates fosters an inequitable situation for Chinese mature students due to unequal distribution of educational resources (Chen, 2015). HE massification has given rise to an imbalance of financial allocation from the government between the RHE and AHE systems. Indeed, Chinese central government and local government prioritise RHE, allocating more financial support to it (Wang, 2016; Yang, 2017).(1)

HE massification has impelled universities to seek more resources, including facilities and teaching space, to accommodate the rapidly enlarging 'regular' student cohort ( $\mathrm{Ji}$, 2013; Yang, 2016). Subsequently, regular universities merged with the former independent adult higher education institutions to form university campuses containing students from both the RHE and AHE systems. However, resources originally assigned to AHE are purported to have been re-directed for the benefit of students in RHE instead (Chen, 2015; Yang, 2016). The temporary patterns of teacher recruitment have also raised concerns over guaranteeing the professionalism of AHE's teachers (Guo, 2015; Wang, 2016). Moreover, lack of government policy to monitor the quality of AHE is 
argued to engender the diminished perceived value of its degrees (Zhao, 2016). Such concerns reverberate throughout the research of Wang (2011), which stands alone as a study yielding qualitative data within the small field of empirical research on AHE. Student participants within Wang's evaluative case study provided negative appraisal of taught content and delivery practices. Case study findings also led Wang to lament a behavioural orientation salient within AHE, namely, the vacuous pursuing of degrees for job-market competitiveness. (2)

\section{2. 'SOCIAL CAPITAL' AND 'GUANXI'}

The concept of social capital in the Anglophone literature is considered opaque, difficult to measure, and has come to be recognised as an umbrella term (Adler and Kwon, 2002; Smart, 1993). A point of convergence between its proponents is that it pertains to a person's access to social resources procured within relationships or interconnections constituting the social fabric of the person's environment. Resources, which not all social capital theorists agree necessarily bring about positive effects, are intangible partly as they represent merely potential benefit based on whether future reciprocal exchanges occur.

Central to conceptions proffered by Bourdieu (1977), famous for propagating the concept, social capital is considered borne out of mutual recognition and solidarity formed out of a long history of shared circumstances in a societal hierarchy. As Rankin (2002) discusses, Bourdieu's conceptualisation of social capital cannot be divorced from its ideological function. However, divergent views have formed in the USA. 
Relative to what was regarded pessimistic theorising on the part of Bourdieu, within the Anglophone literature James Coleman is a notable advocate for social capital's ability to provide the basis for other forms of capital (Field, 2005; Putnam, 2004). Coleman is also argued by Portes (1998) to have provided a distinctive contribution to social capital's conceptualisation, namely, that one's level of social capital is not necessarily determined by one's socio-economic position in a hierarchy. This appears to open up avenues for conceiving of social capital as actively constructed. It must be noted, as Qi (2013) explains, the nature of the social processes connected to social capital remain implicit and difficult to capture by its theorists.

Scholars suggest guanxi is the closest Chinese term for 'social capital' (Chen and Wu, 2011; Gu et al., 2008; Huang and Aaltio, 2014). Guanxi, a combination of two Chinese characters 'guan' meaning 'to close' and 'xi' meaning 'link', represents personal connections among individuals in Chinese society that influence the nature of interpersonal dynamics (Chen and Chen, 2004; Park and Luo, 2001). Core to guanxi are relationships between individuals and 'continual obligation for the exchange of favours' (Dunfee and Warren, 2001, p.192).

In contrast to the westernised social capital concept that emphasises the basis of social interconnections in wider, sociological or demographic categories, guanxi focuses on the many and varied origins of such interconnections and how advantages are actualised through social exchange behaviour at the individual level (Luo et al., 2012). Specifically, social capital developed in western contexts refers to a person's social tie to a group, such as a community (for example, Crowther et al., 2008); in comparison, guanxi becomes formed on initially dyadic ties, namely, those held 
between two persons ( $\mathrm{Li}, 2012)$. Guanxi ties can either be pragmatic, helping individuals to exchange social resources, such as business contacts, or relational in the form of bonds founded upon a trust that builds over protracted periods in which exchange activity occurs. Ties such as those between school peers can contain a blend of both (Chen and Chen, 2004). Guanxi can derive from a variety of characteristics common to the 'dyadic individuals, such as kinship, friendship, acquaintanceship, native origin, and same surname' (Cheng et al., 2014, p.900). What links two people together may not always be obvious, but is generally accepted by people as something that must be sought out actively (Chen and Chen, 2004).

Not dissimilar to the class-based origins of the conceptualisation of social capital conceived by Bourdieu (1977), guanxi has been posited a form of social practice based upon microsocial trust that has evolved alongside, and in response to, changing structural conditions in China (Liu, 2008). Under the communist planned economy, Liu explains guanxi was pivotal in ameliorating anxieties through fostering social exchange in informal circles existing amongst ordinary people, away from the gaze of the state. Despite plentiful resources in the current marketised, globalised era, guanxi has endured to the present day, albeit in an altered form.

When deployed in the field of business, guanxi has been lamented for its instrumentalism as it is reputed to perpetuate asymmetries in access to resources, achieved largely by undercutting formal bureaucratic processes (Qi, 2013). This, Qi notes, has lent guanxi a rather unfortunate notoriety in terms of pushing the boundaries of everyday informal practices, bordering on the unethical. Both positive and negative qualities have been articulated widely across literature conceptualising guanxi (Chen 
and Chen, 2004). Guanxi's endurance and salience in Chinese culture is due to its informality which Qi (2013) argues gives it fortitude over more explicit, formalised exchanges. Further, despite occurring within informal interchanges, guanxi has a purposeful quality. This has been encapsulated by Chen and Chen (2004) who proffer a step-wise blueprint that could be summarised as: select advantageous target from whom the agent needs to take advantage; initially build a relationship with the target; get the benefit; now there is an obligation to reciprocate.

The grounds of social capital and guanxi's comparability, despite obvious social and cultural differences, have been substantiated by Qi (2013) who contends they possess sufficient similarities to warrant their coupling. Social capital lacks the explicit procedural quality of guanxi, but the latter can potentially 'rejuvenate' (Qi, 2013, p. 309) social capital, throwing further light upon the implicit agreements that form the glue between people.

\section{RESEARCH IN HE}

Mature students' marginalisation has been posited widely as a concern and attributed to a fundamentality unequal HE system, both in USA (Sissel, et al. 2001) and UK (Morris, 2009). Attention has been directed to barriers implied by the theoretical notion of differential levels of capital and how these play out in what could be argued the micro-context of university life (for example: Bathmaker et al., 2013; Crozier and Reay, 2011; Reay, 2003). However, social capital as a singular analytic category has not often been coupled with HE. It has arisen as an analytic focus for some over the last two 
decades. As shown in this section, not all explicit users of the concept of social capital in HE research deem it inherently entwined with limited life or educational chances. As a concept, whether adopted to expose social injustice, or advance an understanding of its more positive role in aiding social mobility, Field (2015) argues social capital has received little attention with respect to mature compared to younger students.

In the instances of social capital's adoption in HE contexts, it is conceived of as mutable. Winch's (2000) study, for instance, attests to its role in social mobility. More recently, Fearon et al. (2018) proffer the idea that certain attributes, such as the ability to network with others, bear strongly upon one's chances of personal progression. Jensen and Jetten (2015) place greater emphasis on the connective, relational characteristics of social capital, positing it as enmeshed with belonging, a feeling diminished for those unfamiliar with the rules of the system. They advocate encouraging a bridging form of social capital between tutors and students, as opposed to a bonding form created between peers, to foster a more secure academic identity. Although the above studies take social capital in a rather more optimistic vein than advocates of Bourdieu's (1977) conception of social capital, (for example, Bathmaker et al., 2013), all promulgate the Bourdieusian notion that limited social connectedness and attendant resources is a factor in one's feeling of confidence or security in a context like HE.

Although mature students, partly due to their part-time status, have been characterised as lacking in terms of resources devoted to them (Laird and Pruce, 2009; Price and Baker, 2012), the social networks formed in and around formal campus spaces have stimulated interest as sites for fruitful interactions. As qualitative studies of such 
phenomena have grown, peer support has been noted as especially important among mature students following non-traditional routes (Gilardi and Guglielmetti, 2011; Lundberg, 2003) and is considered capable of providing a unique form of support. Indeed, the informal modes of interaction upon which mature students' social networks are built are deemed by Tett et al. (2012) a facilitator of an important type of learning occurring beyond formal taught sessions, namely, the contextualisation of knowledge and extension of material encountered in lectures. Furthermore, the advantages of such social networks extend far beyond the confines of students' immediate study context, that is, to various life-wide situations including continued employment, maintenance of good health, social integration and social adaptation (Daza, 2016).

\section{METHODOLOGY}

Our qualitative study employs what Roberts (2002) refers to as a biographical interview approach to gain insights into past and present experiences of $30 \mathrm{AHE}$ students, along with the contextual settings within which learning occurs. A large city on the eastern coast has been selected as a representative location for this study, since China's coastal urban belt is widely regarded the educational and economic powerhouse of the country. Within this city, two universities have been selected according to criterion-based purposeful sampling. All interviewee participants are female students of the AHE system, aged 25 to 40 years. At the time of interview (2016), most were working full-time, married and had child dependants. Interviews were recorded and transcribed verbatim, and the transcripts screened and analysed. 


\section{INTERVIEW ANALYSIS}

In this section, excerpts of narratives from interviews are presented, with a particular analytic focus on connections made with fellow students. Analysis of interview data gave rise to emergent themes: a) feelings of isolation leading to reliance upon guanxi with peers; b) resources expected and actively sought out; c) intentional maintenance of guanxi with peers to store potential benefit for the long-term.

\section{a) Feelings of Isolation Leading to Reliance on Guanxi with Peers}

Interviewees articulate what they feel to be their position relative to those in RHE, deeming the AHE cohort to be subordinate. Despite having lectures on university campus, they speak of being barred from resources on campus, perceiving them to belong solely to RHE students,

...we can enter the library but we can only read books inside and we are not allowed to borrow books and take them out. Our student card is different from the full-time [RHE] students so we cannot use the Wi-Fi on campus; we cannot use the university website either, because we cannot get access to the internet by using our student number. (31yrs, Yrl)

Interviewees speak of feeling denied the forms of support and access to resources available to those they deem 'authentic' students, namely, those within RHE. The segregation they refer to contributes to feeling isolated as a cohort of 'mature students';

Those [RHE] students are the dominant and authentic students in university and the university does not think highly of us mature students. 
The university does not care about us or want to spend much effort on us. (25yrs, Yr3)

Feeling 'neglected' by the university is cited as the reason for turning to peers. Opportunities for bridging capital, with those in the wider campus community such as their RHE counterparts appear limited. The perception that the 'university does not care for us' is compounded by a sense of disconnection from teaching staff. Module teachers are described as unwilling to offer help or answer questions and 'leave the classroom as soon as they finish the lectures',

...our teachers show no willingness to care for us or help us. When we come to them with questions their attitude is unsupportive...so we are unwilling to ask them again. Then I have to have a good guanxi with my peers who are the only ones I can rely on. (29yrs, Yrl)

Guanxi with peers is highly valued by interviewees for yielding desired resources in terms of studying and is considered reliable since it can be readily turned to as and when required. They contrast this to the paucity of support from teachers. Interviewees' proactivity in terms of seeking and maintaining guanxi with peers resonates with Bian's (2018) postulation that integral to guanxi is the purposeful bolstering of the most personally fruitful, instrumental ties in one's immediate social network. Interviewees strengthen such ties through the regular, repeated exchange activity they describe, which Bian would identify as fundamental to guanxi.

Interviewees consider peers' company to be critical to completing,

There are 80 students in my class and teachers do not know who I am...so if I didn't have people in my class for company I would feel quite isolated and lonely, and maybe not complete the study (26yrs, Yr3). 
The unity they claim it generates resonates with Reay et al.'s (2002) contention that mature students, perhaps through feeling non-mainstream, connect on the basis of perceived similarity and subsequently obtain mutual self-validation. Our interviewees suggest peers are the only people they can turn to, though ties created appear as instrumental as they are emotional. They reflect the blend of emotional and instrumental qualities that Chen and Chen (2004) deem prevalent among guanxi between school peers. Rather than referring to emotional resources directly, they adopt the term 'company'. Such connectivity is not likened to that of close friendship:

...guanxi with peers not only provides me with practical benefit, but also gives me company... although they are not my close friends. (26yrs, Yr3)

\section{b) Resources Expected and Actively Sought Out}

Apparent in interviewees' narratives are the expectations propelling their construction of guanxi with peers along with processes involved in favour exchange. Those they describe reflect social norms within guanxi that Qi (2013, p.314) would characterise as 'renqing'. The tacit expectation - integral to the working of guanxi - is the offering of resources upfront to initiate tie formation. Its processual nature is illustrated below,

There are some students in our class who keep notes very well. Because I do not keep notes and want to have a good scores in exams, I keep a good guanxi with them by offering what help they need. Then when I need to ask them for help I can because of our guanxi. (26yrs, graduated) 
Interviewees allude to the reciprocal exchange of favours in this setting as 'support', explaining it includes provision of material to aid comprehension. It appears to involve collaboration to find expedient routes to the ends envisaged. For example, they speak of circumventing the practices implemented by the university that they consider obstructive, such as the attendance monitoring system. The perceived resource, namely, signing in on behalf of an absent peer is generated this way.

Such strategies for providing 'support', facilitated by guanxi, also appear founded upon distrust of teachers to deliver relevant or consistent teaching content. Faith is placed in peers as providers of desired resources. Double-checking with a peer that revision material received from module teachers is correct is a resource procured via dyadic ties. They speak of strategies for mitigating for conflicting revision material given by the various teachers encountered on a module. The peer in another class with whom they form such a dyadic tie does not have to be someone they know well: the tie is based upon pragmatic, mutual favour exchange, in a situation in which they have identified a common, practical need,

...we tell each other what the teacher says...[the peer] is an important resource for me to have a higher score in exams... so we maintain our guanxi well although we are not close friends. (28yrs, $\mathrm{Yrl}$ )

A salient resource interviewees state they expect to gain from guanxi with peers is assistance in understanding assignment requirements,

... senior students here have helped a lot. They give me assignments they have done before to let me know how to do it. They give me their notes 
which I can turn to when I do not understand the teaching context. (25yrs, Yr3)

They speak of having greater confidence in each other's knowledge than lecture content, which they consider 'really outdated'. This chimes with Chen's (2015) contention that textbooks developed for the disciplines within the AHE system have not been updated or modernised for over a decade. Interviewees consider it irrelevant to their working lives and consequently place little value upon it.

They deem a paucity of practice-focused, contemporary course content another reason for relying upon guanxi with peers. Peers' knowledge gained from work experience is regarded a richer source of professional learning than lecture content. Faith in and valuing of one another's professional experience, as well as knowledge of which module materials to trust, strengthens these ties,

Because the university does not provide us with teaching of practical skills, I need to rely on my guanxi with my peers to learn practical working experience. (25yrs, $\operatorname{Yr} 3)$

c) Intentional Maintenance of Guanxi with Peers to Store Potential Benefit for the Long-term

Interviewees emphasise the importance of maintaining good guanxi with peers for long-term benefit. This must be taken in the context of China's highly competitive graduate job-market, propagated by HE massification (Jiang, 2017). As Bian (2018) explains, empirical studies investigating wider patterns of job search strategies indicate 
that guanxi as a social practice has come to the fore. Bian notes that such proclivity to deploy guanxi to expedite job opportunities occurs despite the increasing influence of marketised approaches. The latter might be assumed to run contra to the underhand binding agreements integral to guanxi; indeed, agreements within market transactions are typically of a more explicit variety. For interviewees, guanxi with peers is considered critical to long-term storage of resources such as job references, or know how in terms of professional practice. The latter is not considered by them to be supported in course content. Implied in the excerpts below is the notion of needing to be sufficiently resourced as an individual, as though prepared for the competition in the job-market that Wang (2011) and Jiang (2017) postulate,

All my classmates now work in kindergartens....now I have to find a job in a good kindergarten so have to ask my classmate to be my referee to introduce me to her kindergarten. Now my classmates are just teachers in their kindergarten... after a few years they will have promotion and become leaders in their kindergarten.... so maintaining the guanxi with them is very important. (34yrs, yrl)

My peers work in various kindergartens... different kindergartens have their special features such as teaching design or activity design. We can learn various things from each other. Their work experience is a priceless resource for me.... so I want to maintain our guanxi even after graduation. (33yrs, yr3)

Guanxi is also considered to procure personalised assistance tailored to professional practice and personal situation. Interviewees enthuse over guanxi's role in the acquisition of specific forms of help from peers, unique to their individual needs. This appears facilitated by going beyond exchanging practical forms of help to sharing in matters of 'personal life': 
We like to maintain a good guanxi with each other so create many opportunities to get close to each other. We have lunch together every Sunday on the big grass area - like a picnic - and keep this as a routine. We share our work and personal life in order to maintain and have a closer guanxi with each other, which enables us to feel comfortable to ask each other for help. (35yrs, Yrl)

While such sharing fosters feeling at ease with one another, it ultimately seems a strategy for oiling the wheels so they feel more able to favour-seek. Thus, in this context, relational qualities of guanxi are infused with pragmatism.

\section{DISCUSSION}

Interviewees' cognisance of the moves they need to make to inaugurate guanxi with peers is reflected in their accounts of their motivations and actions. Such active pursuit of 'good guanxi' to obtain resources could extend the conceptualisation of social capital in the West. In the aforementioned Anglophone literature, Bathmaker et al. (2013) postulate an arguably received form of social capital, in so far that it manifests in students' inherited access to networks, or pre-given capacity to activate them. Conversely, AHE student interviewees engage the norms of guanxi as a social practice to develop their networks. The active construction of guanxi, starting from dyadic ties, facilitates the opening up of social capital to the notion of its purposive cultivation. The step-wise processes pertaining to the initiation of ties, identification of a common need to consolidate the tie and expectation of reciprocity are captured in our study. They provide further substantiation to Qi's (2013, p.309) theoretical argument that guanxi can 'rejuvenate' social capital. Whether such intentional behaviour and readiness to 
construct one's social networks transfers to national contexts that do not engage guanxi is a matter for future inquiry.

The proactivity on the part of interviewees in constructing their guanxi lends a degree of support to the more optimistic notions of social capital that eschew its structurally determined nature (see Portes, 1998). Even before graduating, interviewees augment guanxi with peers to procure anticipated benefits. However, assuming such proactivity is unaffected by societal structures and associated inequality would be to ignore the Bourdieusian influence upon social capital's conceptualisation. It would also overlook current conditions regarding China's intensely competitive graduate employment landscape (Jiang, 2017). As Qi (2013) clarifies, informal agreements arising from relations of trust agglutinate the networks that are able to confer certain privileges; pertinently, the limited nature of such networks and inequitable access to them and prized resources embedded therein thus raise comparable concerns over inequality.

An aspect of guanxi also highlighted in our study is its fostering of highly personalised resources, as Bian (2018) would attest. Interviewees could be argued to engage a social practice that they recognise collectively as way of catalysing the exchange of information that might slip through the net of formalised channels and patterns of interconnectivity. Such tendencies to use informal connections to procure particular resources in wider society stem, Bain explains, from a past characterised by resource impoverishment. Ties are made intentionally 'strong' (Bian, 2018, p.605) from being deemed most likely to yield resources. From the perspective of social capital, interviewees' concentration on connections with those deemed to have similar characteristics or needs may be construed as a proclivity for bonding over bridging. 
Rather than characterising their reliance on guanxi with peers to yield resources as habitual parochialism - as though bonding is selected freely over bridging capital - it could be argued to be a concerted effort to counter the effects of scarce conditions. Thus social connectivity, at the micro-level, is not just a shaped around the familiar practices and social norms of guanxi, but conditioned by wider structural forces and political intervention in HE. Under-resourcing is indeed perceived by interviewees, echoing the concerns of Wang (2016), Yang (2005) and Yang (2017) who lament the uneven allocation of resources across types of HE in China.

Taking structuralist arguments further, interviewees' reliance on guanxi with peers to compensate for what appears a paucity of provision could inadvertently reinforce the workings of what Jiang (2017) defines as a profoundly marketised HE landscape. In other words, it potentially mitigates for damages brought to equality arising from a political strategy ultimately championing competitiveness over social redistribution (Jiang, 2017; Yang, 2005). Such a concern is further inflected in Shan and Guo's (2014) contention that equity issues are not readily picked up by research into the effects of the transformation of China's HE since policy documents purvey predominantly marketised discourses, as though education is a mere servant of the economy. This way, issues of inequality become submerged.

\section{CONCLUSION}

This study elucidates the self-initiated, processual nature of guanxi in the context of China's AHE and helps articulate the shortest conceptual bridges between guanxi and 
social capital. Interview data are limited to students' perceptions, in terms of their expressed motivations for augmenting guanxi with peers. Therefore, it is not possible to discern the longevity of such ties, or realisation of the benefit students anticipate. Nevertheless, pursuing the relational components, subsumed within social capital distinctively, illuminates how the processes of inaugurating social capital fuse with the norms of a culturally embedded social practice, namely, guanxi. Further investigation across national contexts, attuned to both structural and micro social elements, could confirm social capital's utility and flexibility as a concept integral to investigating HE inequality internationally.

\section{NOTES}

(1) For instance, in 2014, central government allocated 81.8 billion (Chinese yuan) to RHE (MoE, 2014) and 19.7 billion (Chinese yuan) to AHE (MoE, 2016b).

(2) Wang's (2011) study did not incorporate the concepts social capital or guanxi.

\section{REFERENCES}

\section{Anglophone Literature}

Adler, P.S. and Kwon, S-W. (2002) Social capital: prospects for a new concept, The Academy of Management Review, 27(1), 17-40. 
Bathmaker, A.M., Ingram, N. and Waller, R. (2013) Higher education, social class and the mobilisation of capitals: Recognising and playing the game, British Journal of Sociology of Education, 34(5-6), 723-743.

Bian, Y. (2018) The prevalence and the increasing impact of Guanxi, The China Quarterly, 235, 597-621.

Bourdieu, P. (1977) Outline of a theory of practice (Cambridge, University Press).

Chen, X. P. and Chen, C. C. (2004) On the intricacies of the Chinese Guanxi: A process model of Guanxi development, Asia Pacific Journal of Management, 21, 305-324.

Chen, X. and Wu, J. (2011) Do different guanxi types affect capability building differently? A contingency view, Industrial Marketing Management, 40, 581-592.

Cheng, M-H., Chang, Y-Y. and Lee, C-L. (2014) Creative entrepreneurs' guanxi networks and success: information and resource, Journal of Business Research, 68, 900-905.

Crozier, G. and Reay, D. (2011) Capital accumulation: working-class students learning how to learn in Higher Education, Teaching in Higher Education, 16(2), 145-155.

Crowther, J., Tett, L. and Edwards, V. (2008) Building connections, getting involved: measuring social capital outcomes of community learning and development. Report for the Scottish Government (Edinburgh, University of Edinburgh).

Daza, L. (2016) The role of social capital in students' perceptions of progress in higher education, Educational Research and Evaluation, 22(1-2), 65-85.

De Vries, R. and Renfrow, J. (2016) A winning personality: the effects of background upon personality and earnings (Sutton Trust/University of Cambridge/University of Kent).

Dunfee, T. W. and Warren, D.E. (2001) Is Guanxi Ethical? A Normative Analysis of Doing Business in China, Journal of Business Ethics 32(3), 191-204.

Fearon, C., Nachmias, S., McLaughlin, H. and Jackson, S. (2018) Personal values, social capital, and higher education student career decidedness: a new 'protean'informed model, Studies in Higher Education, 43(2), 269-291.

Field, J. (2005) Social capital and lifelong learning (Bristol, The Policy Press).

Field, J. (2015) Social ties, agency and change: education and social capital in adult life. In Li, Y. (Ed) Handbook of research methods and applications in social capital (Cheltenham, Edward Edgar Publishing Ltd), 292-306. 
Gilardi, S. and Guglielmetti, C. (2011) University life of non-traditional students: Engagement styles and impact on attrition, The Journal of Higher Education, 82(1), 33-53.

Gu, F. F., Hung, K. and Tse, D. K. (2008) When does guanxi matter? Issues of capitalization and its dark sides, Journal of Marketing, 72, 12-28.

Huang, J. and Aaltio, L. (2014) Guanxi and social capital: networking among women managers in China and Finland, International Journal of Intercultural Relations, 39, 22-39.

Jensen, D. H. and Jetten, J. (2015) Bridging and bonding interactions in higher education: social capital and students' academic and professional identity formation, Frontiers in psychology 6 (126), 1-11.

Jiang, J. (2017) Higher Education in China, Oxford research encyclopaedia in Education. Available at:

http://oxfordre.com/education/view/10.1093/acrefore/9780190264093.001.0001/acref ore-9780190264093-e-207 (accessed April 2019).

Laird, T. F. N. and Cruce, T. M. (2009) Individual and environmental effects of parttime enrolment status on student-faculty interaction and self-reported gains, The Journal of Higher Education 80(3), 290-314.

Li, P. P. (2012) Toward an Integrative Framework of Indigenous Research: The Geocentric Implications of Yin-Yang Balance, Asia Pacific Journal of Management 29 (4), 849-872.

Liu, L. (2008) Filial Piety, Guanxi, Loyalty and Money. In Markova and Gillespie (Eds) Trust and distrust (USA, Information Age Publishing Inc.), 51-77.

Lundberg, C. A. (2003) The influence of time-limitations, faculty, and peer relationships on adult student learning: A causal model, The Journal of Higher Education, 74(6), 665-688.

Luo, Y., Huang, Y., and Wang, S. L. (2012) Guanxi and Organizational Performance: A Meta-Analysis, Management and Organization Review 8(1), 139-172.

Morris, A. (2009) The stretched academy: The learning experience of mature students from under-represented groups. In Bell, L., Stevenson, H. and Neary, M. (Eds) The future of higher education. Policy, pedagogy and the student experience (London, Continuum), 99-111.

Park, S. H. and Luo, Y. (2001) Guanxi and organizational dynamics: Organizational networking in Chinese firms, Strategic Management Journal, 22, 455-477.

Portes, A. (1998) Social capital: its origins and applications in modern sociology, Annual Review of Sociology, 24, 1-24. 
Price, K. and Baker, S. N. (2012) Measuring students' engagement on college campuses: Is the NSSE an appropriate measure of adult students' engagement? The Journal of Continuing Higher Education, 60(1), 20-32.

Putnam, R.D. (2004) Democracies in flux: the evolution of social capital in contemporary society (New York, Oxford University Press).

Qi, X. (2013) Guanxi, social capital theory and beyond: toward a globalized social science, The British Journal of Sociology, 64(2).

Rankin, K.N. (2002) Social capital, microfinance and the politics of development, Feminist Economics, 8(1), 1-24.

Reay, D., Ball, S. and David, M. (2002) 'It's taking me a long time but I'll get there in the end': Mature students on access courses and higher education choice, British Educational Research Journal, 28(1), 5-19.

Reay, D. (2003) A risky business? Mature working class women students and access to higher education, Gender and Education, 15(3), 301-317.

Roberts, B. (2002) Biographical Research (Buckingham, Open University Press).

Shan, H. and Guo, S. (2014) Massification of Chinese education: opportunities and challenges in a globalising context. In Kariwo, M., Gounko, T. and Nungo, M. (Eds) $A$ comparative analysis of Higher Education systems: issues, challenges and dilemmas (Rotterdam, Sense Publishers), 9-24.

Sissel, P. A., Hansman, C. A. \& Kasworm, C. E. (2001) The politics of neglect: adult learners in higher education. New Directions for Adult and Continuing Education, 2001(91), 17-28.

Smart, A. (1993) Gifts, bribes and guanxi: a reconsideration of Bourdieu's social capital, Cultural Anthropology, 8(3), 388-408.

Tett, L., Hounsell, J., Christie, H., Cree, V. E. and McCune, V. (2012) Learning from feedback? Mature students' experiences of assessment in higher education, Research in Post-Compulsory Education, 17(2), 247-260.

Wang, N. and Morgan, J.W. (2009) Student motivations, quality and status in adult higher education (AHE) in China, International Journal of Lifelong Education, 28(4), 473-491.

Wang, N. (2011) Adult Higher Education in China: problems and potential. In Morgan. W.J. and Wu, B. (Eds) Higher Education reform in China: beyond the expansion, (Oxon, Routledge), 30-47. 
Winch, C. (2000) Education, work and social capital: towards a new conception of vocational education (London, Routledge).

Yang, R. (2005) Higher Education in the people's republic of China: historical traditions, recent developments and major issues. Paper presented to the $5^{\text {th }}$ National and $4^{\text {th }}$ International "Challenges and expectations of the university": experiences and dilemmas of the reformation, Universitidad Autonoma de Tamaulipas, Mexico, 8-10 June 2005.

\section{Chinese Literature}

Chen, S. L. (2015) Comparison and development countermeasures between Adult Higher Education and General Higher Education, Asia Pacific Education, 08, 13-14. 陈世立. 成人高等教育与普通高等教育的对比及发展对策 $[\mathrm{J}]$. 亚太教育.

Guo, H. Y. (2015) The problems and countermeasures of the construction of Adult Education teachers in colleges and universities, Continuing Education, 23, 119-121. 国 海英. 高校成人教育教师队伍建设的问题与对策 $[\mathrm{J}]$.继续教育.

Ji, C. W. (2013) Study on the problems of Higher Education run by adults in Higher Education, Continuing Education, 27(07), 21-22. 季传武. 普通高等教育学校兼办成 人高等教育问题研究 $[\mathrm{J}]$. 继续教育.

MoE (2014) (Ministry of Education of the People's Republic of China). Financial allocation to RHE in the year 2014. Available at:

http://www.moe.gov.cn/srcsite/A05/s7499/201404/t20140418_167426.html (accessed October 2018).

MoE (2016a) (Ministry of Education of the People's Republic of China). Enrolment number of undergraduate students in the year 2016. Available at: http://www.moe.edu.cn/s78/A03/moe_560/jytjsj_2016/2016_qg/201708/t20170823_3 11668.html (accessed October 2018)

MoE (2016b) (Ministry of Education of the People's Republic of China). Financial allocation to AHE in the year 2014. Available at: http://www.moe.gov.cn/jyb_xxgk/xxgk_jyta/jyta_ghs/201612/t20161206_290968.ht $\underline{\mathrm{ml}}$ (accessed October 2018).

Qin, J. W. (2016) Discussion on the development strategy of Adult Higher Education under the trend of popularization of Higher Education, Continuing Education Research, $8,70-72$. 秦建伟. 高等教育大众化趋势下成人高等教育发展策略探讨 $[\mathrm{J}]$. 继续教 育研究.

Wang, X. Y. (2016) The countermeasures of Adult Higher Education innovation and development under the background of Higher Education popularization, The Research 
of Continuing Education, 6, 43-45. 王晓燕. 高等教育大众化背景下成人高等教育创 新发展的对策 $[\mathrm{J}]$. 继续教育研究.

Wang, Y. S. and Jiao, Y. C. (2016) A Study on the factors affecting the quality of Higher Education admission, Journal of Higher Education in Jiangsu Province, 3, 3135. 汪雅霜,矫怡程. 高等教育入学机会质量获得影响因素研究[J]. 江苏高教.

Yang, X. J. (2016) The quality imbalance and the return of nature in the development of Adult Higher Education in China, The Research of Continuing Education, 7, 54-56. 杨晓军. 我国成人高等教育发展的“质量”失衡与本性回归 $[\mathrm{J}]$. 继续教育研究.

Yang, Z. C. (2017) The influence of enrolment expansion on the economic returns of Adult Higher Education, Journal of National Academy of Education Administration, 04, 49-56. 杨中超. 教育扩招对成人高等教育经济回报的影响研究[J]. 国家教育行 政学院学报.

Yu, X. B. (2010) A Study on the transformation of Chinese Adult Higher Education (Hunan, Hunan University Press), 余小波. 中国成人高等教育转型研究[M]. 湖南: 湖南大学出版社.

Zhao, G. H. (2016) Research and thinking on the quality of Adult Higher Education. Journal of Hebei Radio \& TV University, 21(06), 1-4. 赵贵河. 成人高等教育质量问 题研究与思考 $[\mathrm{J}]$. 河北广播电视大学学报. 